\title{
Aktivitas Antiangiogenesis Ekstrak Daun Dewandaru (Eugenia uniflora L.) pada Retina Tikus Wistar yang Diinduksi Streptozotocin
}

\section{Antiangiogenesis Activity of Dewandaru (Eugenia uniflora L.) Leaf Extract in Wistar Rats Retina Induced Streptozotocin}

\author{
Karina Ayu Nilamsari ${ }^{1 *}$, Nurmawati Fatimah ${ }^{2}$, Gwenny Ichsan Prabowo ${ }^{3}$ \\ ${ }^{1}$ Pendidikan Dokter, ${ }^{2}$ Departemen Farmakologi, ${ }^{3}$ Departemen Biokimia, \\ Fakultas Kedokteran, Universitas Airlangga \\ *Corresponding author: karinaayunilamsari09@gmail.com
}

\begin{abstract}
Abstrak
Retinopati diabetik adalah komplikasi vaskular yang paling spesifik dari kedua tipe diabetes. Penyebab retinopati diabetik adalah adanya angiogenesis. Angiogenesis diinduksi oleh aktivasi Vascular Endothelial Growth Factor (VEGF). Kandungan Quercetin, salah satu flavonoid yang ada dalam daun Dewandaru (Eugenia uniflora L.) dapat menghambat VEGF. Penelitian ini bertujuan untuk mengetahui akativitas angiogenesis ekstrak Eugenia uniflora L. pada retina tikus yang diinduksi Streptozotocin (STZ). Penelitian ini menggunakan True Experimental Laboratory melalui metode Randomized Posttest Only Controlled Group Design dengan tikus wistar jantan yang dibagi menjadi 5 kelompok, yaitu kelompok kontrol negatif (K-) yang hanya diberikan diet standar tikus, pemberian STZ yaitu dengan dosis $40 \mathrm{mg} / \mathrm{kgBB}$ secara injeksi di intraperitoneal diberikan pada kelompok kontrol positif (K+), dan kelompok perlakuan (P1, P2, P3) dan dosis pemberian ekstrak Eugenia uniflora $L$. yaitu $\mathrm{P} 1=50 \mathrm{mg} / \mathrm{kgBB}, \mathrm{P} 2=100 \mathrm{mg} / \mathrm{kgBB}$, dan $\mathrm{P} 3=200 \mathrm{mg} / \mathrm{kgBB}$ secara peroral sehari sekali. Selama 1 bulan perlakuan, hasil glukosa darah 1 dan 2, kelompok K (-), K (+), dan P3 menunjukkan peningkatan kadar glukosa, sedangkan P1 dan P2 menunjukkan penurunan kadar glukosa. Selama penelitian K (-), K (+), P1, P2, P3 menunjukkan peningkatan berat badan. Hasil pewarnaan HE didapatkan penurunan jumlah pembuluh darah pada kelompok perlakuan dengan perbedaan signifikan antara kelompok penelitian $(\mathrm{p}<0.05)$. Dapat disimpulkan bahwa pemberian ekstrak Eugenia uniflora L. pada retina tikus Wistar yang diinduksi STZ berpotensi menurunkan respon angiogenesis pada retina tikus yaitu dengan menurunkan jumlah pembuluh darah retina tikus.
\end{abstract}

Kata kunci: Retinopati diabetik, Daun Dewandaru, Eugenia uniflora L., angiogenesis, retina

\begin{abstract}
Diabetic retinopathy is the most specific vascular complication of both types of diabetes. One cause of diabetic retinopathy is the presence of angiogenesis. Angiogenesis is induced by the activation of Vascular Endothelial Growth Factor (VEGF). The content of Quercetin, one of the flavonoids present in the leaves of Eugenia uniflora L. can inhibit VEGF. This study aimed to determine antiangiogenesis activity of Dewandaru (Eugenia uniflora L.) leaf extract in retina rats. This study uses a True Experimental Laboratory through the Randomized Posttest Only Controlled Group Design method with male wistar rats divided into 5 groups, namely the negative control group $(\mathrm{K}-)$, positive control $(\mathrm{K}+)$, and 3 treatment groups (P1, P2, P3). Streptozotocin administrated at a dose of $40 \mathrm{mg} / \mathrm{kgBW}$ by injection in intraperitoneal. The dose of Eugenia uniflora $L$. extract is $\mathrm{P} 1=50 \mathrm{mg} / \mathrm{kgBB}, \mathrm{P} 2=100 \mathrm{mg} / \mathrm{kgBB}$, and $\mathrm{P} 3=200 \mathrm{mg} / \mathrm{kgBB}$ per once a day, during 1 month of treatment. Blood glucose results 1 and 2, groups $\mathrm{K}(-), \mathrm{K}(+)$, and P3 showed an increase in glucose levels, whereas P1 and P2 showed a decrease in glucose levels. During the study K (-), K (+), P1, P2, P3 showed weight gain. The results of HE staining decreased the number of blood vessels in the treatment group with a significant difference between the study groups $(\mathrm{p}<0.05)$. A can be concluded that Eugenia uniflora $L$. leaf extract in Retina Wistar has the potential to reduce the response of angiogenesis.
\end{abstract}

Key words: Diabetic retinopathy, Dewandaru leaves, Eugenia uniflora L., angiogenesis, retina 


\section{PENDAHULUAN}

Retinopati diabetik adalah komplikasi vaskular yang paling spesifik dari kedua tipe diabetes, baik tipe 1 maupun tipe 2. Retinopati diabetik paling sering menjadi penyebab munculnya kasus baru kebutaan, yaitu pada rentang usia dewasa antara 20-74 tahun. Glaukoma, katarak, dan gangguan lainnya muncul lebih awal dan lebih sering pada orang yang dinyatakan positif mengalami penyakit diabetes (Cunha-Vaz, 2011).

World Heatlh Organization (WHO) mengatakan setidaknya ada seratus lima puluh juta orang di seluruh dunia telah menderita retinopati diabetik dan diproyeksikan jumlah tersebut akan meningkat dua kali lipat pada tahun 2025 (Soebagijo, 2015). Data RISKESDAS tahun 2013, yaitu sebesar 33.40\% yang didapatkan pada penderita diabetes yang dirawat di RSCM tahun 2011. The Diabetes Care Asia 2008 Study melibatkan 1785 penderita diabetes mellitus (DM) pada 18 pusat kesehatan primer dan sekunder di Indonesia, melaporkan bahwa $42 \%$ penderita diabetes mellitus mengalami komplikasi retinopati, dan $6,4 \%$ di antaranya merupakan retinopati diabetik proliferatif (Sitompul, 2011).

Penyebab retinopati diabetik salah satunya adalah akibat hiperglikemia yang mengaktivasi transduksi sinyal intraseluler protein kinase-C (PK-C). PK-C tersebut kemudian mengaktivasi vascular endothelial growth factor (VEGF) dan faktor pertumbuhan lain (Hamid et al., 2019). VEGF menstimulasi ekspresi intracellular adhesion molecule-1 (ICAM-1) yang memicu terbentuknya ikatan antara leukosit dan endotel pembuluh darah. Ikatan tersebut menyebabkan kerusakan sawar darah retina, serta trombosis dan oklusi kapiler retina (Sitompul, 2011). Selain itu, VEGF juga berikatan dengan reseptornya, yaitu vascular endothelial growth factor receptor 2 (VEGFR-2) yang kemudian akan menyebabkan fosforilasi tirosin kinase dan tranduksi sinyal yang lain yang dapat menyebabkan angiogenesis (Gupta $d k k, 2013$ ).

Kandungan Eugenia uniflora L. diantaranya saponin, flavonoida (berupa quercetin, mycitrin, gallocatechin, dan quecutrin), alkaloida, tanin, rubixanthin, sitronella, sineol, piperidin, antosianin, phytofluene, $\quad \beta$-crytoxanthine, lycopene, $\beta$-karoten, $\gamma$-karoten, dan c-karoten. Hasil penelitian menunjukkan bahwa ekstrak etanolik daun dewandaru memiliki aktivitas antioksidan, antibakteri, penghambat hidrolisis dan oksidasi enzim, serta sebagai antiinflamasi. Daun Dewandaru juga menunjukkan aktifitas sitotoksik terhadap sel kanker payudara T47D dan menunjukkan efek sinergistik dengan agen kemoterapi doxorubisin pada sel tersebut (Kusumowati dkk., 2010). Penelitian tersebut berhubungan dengan penghambatan peningkatan VEGF oleh flavonoid yang ada di Eugenia uniflora $L$. Penelitian mengenai pengaruh pemberian ekstrak daun Eugenia uniflora $L$. sebagai antiangiogenesis pada retina tikus Wistar yang diinduksi Streptozotocin (STZ) perlu dilakukan.

\section{METODE PENELITIAN}

\section{Desain Penelitian}

Penelitian ini menggunakan rancangan True Experimental Laboratory melalui metode Randomized Posttest Only Controlled Group Design.

\section{Pembuatan Ekstrak Daun Eugenia uniflora L.}

Ekstrak daun Eugenia uniflora L. dalam bentuk ekstrak kasar (serbuk) dibuat melalui prosedur ekstraksi dengan pelarut etanol $96 \%$. Ekstrak daun dewandaru peroral menggunakan sonde lambung kepada kelompok perlakuan, dimana pada kelompok P1 dengan dosis 50 $\mathrm{mg} / \mathrm{kgBB}$, kelompok P2 dengan dosis 100 $\mathrm{mg} / \mathrm{kgBB}$, dan kelompok P3 dengan dosis 200 $\mathrm{mg} / \mathrm{kgBB}$. Pemberian dilakukan dalam satu kali sehari pada sore hari. Prosedur pembuatan ekstrak daun Eugenia uniflora L. dilakukan di Materia Medica Dinas Kesehatan Provinsi Jawa Timur, Batu dan Laboratorium Farmakologi Fakultas Kedokteran Universitas Airlangga, Surabaya.

\section{Pengukuran Glukosa Darah Tikus}

Kadar glukosa darah adalah jumlah kandungan glukosa dalam plasma darah. Kadar glukosa darah sebelum induksi STZ normal (80$120 \mathrm{mg} / \mathrm{dl}$ ), kadar glukosa darah setelah induksi STZ >120mg/dl (hiperglikemia), dan > 200 $\mathrm{mg} / \mathrm{dl}$ (tikus benar-benar diabetes mellitus). Kadar glukosa dalam darah diukur dengan 
glukometer digital dengan pengambilan sampel darah kapiler pada bagian ujung ekor tikus dimana tempat pertemuan pembuluh darah dengan menggunakan lancet.

\section{Penimbangan Berat Badan Tikus}

Berat badan adalah berat tikus jantan putih (Rattus norvegicus) galur Wistar jantan usia 8-9 minggu yang diukur dengan timbangan analitik. Berat diukur dalam satuan gram. Tikus yang dipilih dalam penelitian ini, memiliki berat badan antara 150 - 250 gram.

\section{Perhitungan Jumlah Pembuluh Darah Retina Tikus}

Hasil perhitungan jumlah pembuluh darah retina yang dilakukan dengan pewarnaan Hematoxylin-Eosin (HE), dianalisa dengan menggunakan software Olyvia pada pembesaran 400x. Pembuluh darah memiliki lapisan endotel yang berisi sel endotel berinti gepeng, terletak memanjang sesuai dengan aliran darah, berwarna biru dan menonjol ke dalam lumen, juga dikelilingi oleh selubung tipis atas serat kolagen dan elastin tipis disertai sel perivaskular (perisit) yang berasal dari mesenkim dengan cabang cabang sitoplasma panjang yang mengelilingi sebagian sel - sel endotel, memiliki membrane basalis, serta adanya eritrosit di dalam lumen.

\section{Proses Perlakuan pada Hewan Coba}

Pada surat keterangan kelaikan etik No.196/EC/KEPK/FKUA/2018, persiapan hewan coba dimulai dengan mempersiapkan alat dan bahan penelitian yang akan digunakan dan dilakukan seleksi tikus berdasarkan kriteria inklusi. Tikus diaklimatisasi selama 7 hari dengan diberi diet normal.

Setelah aklimatisasi, tikus dibagi menjadi 5 kelompok yaitu, Kelompok kontrol negatif (K-) 6 ekor tikus Wistar jantan tanpa diinduksi STZ dan diberikan diet standar tikus. Kelompok kontrol positif $(\mathrm{K}+) 6$ ekor tikus Wistar jantan dalam keadaan diabetes yang dibuat dengan diinduksi STZ $40 \mathrm{mg} / \mathrm{kgBB}$ dan diberikan diet standar tikus. Kelompok perlakuan (P1) 6 ekor tikus Wistar jantan dalam keadaan diabetes yang dibuat dengan diinduksi STZ $40 \mathrm{mg} / \mathrm{kgBB}$ dan diberikan personde $50 \mathrm{mg} / \mathrm{kgBB}$ ekstrak Daun Eugenia uniflora $L$. pada sore hari serta diberikan diet standar tikus. Kelompok perlakuan (P2) 6 ekor tikus Wistar jantan dalam keadaan diabetes yang dibuat dengan diinduksi STZ $40 \mathrm{mg} / \mathrm{kgBB}$ dan diberikan personde 100 mg/kgBB ekstrak Daun Eugenia uniflora L. pada sore hari serta diberikan diet standar tikus. Kelompok perlakuan (P3) 6 ekor tikus Wistar jantan dalam keadaan diabetes yang dibuat dengan diinduksi STZ $40 \mathrm{mg} / \mathrm{kgBB}$ dan diberikan personde $200 \mathrm{mg} / \mathrm{kgBB}$ ekstrak Daun Eugenia uniflora $L$. pada sore hari serta diberikan diet standar tikus. Ekstrak Daun Eugenia uniflora L. diberikan pada minggu ke-3 secara peroral dengan menggunakan sonde.

Pada akhir minggu ke-5 paska pembedahan dan pengambilan retina pada tikus, dilakukan pemeriksaan histopatologis. Tikus di euthanasia dan setelah dilakukan pengambilan retina dimasukkan dalam larutan formalin $10 \%$ untuk difiksasi sebagai bahan pewarnaan HematoxylinEosin untuk penilaian mikroskopis dan dianalisa menggunakan software Olyvia (viewer for histological examination).

\section{Analisis Data}

Data hasil penelitian disajikan dalam mean \pm SD. Kemudian semua data dianalisis menggunakan software SPSS versi 16 dengan metode statistik parametrik One-way ANOVA setelah memenuhi uji normalitas data dan uji homogenitas varian. Apabila syarat dari uji oneway ANOVA tidak terpenuhi, maka dipilih uji non-parametric Kruskal-Wallis. Analisa data dengan derajat kepercayaan $95 \%$ dan $\alpha=0.05$.

\section{HASIL DAN PEMBAHASAN}

\section{Pengukuran Glukosa Darah Tikus}

Pengukuran glukosa darah dilakukan dua kali selama masa perlakuan, yaitu pada tiga hari setelah injeksi STZ dan dua minggu setelahnya. Data tersebut diketahui bahwa (K-) yang tidak diinjeksi STZ menunjukan kadar glukosa darah yaitu $96.50 \pm 13.22 \mathrm{mg} / \mathrm{dl}$ pada glukosa darah ke1 dan $114.17 \pm 24.45 \mathrm{mg} / \mathrm{dl}$ pada glukosa darah ke-2 yang termasuk dalam rentang kadar glukosa 
Tabel 1. Data rata-rata pengukuran glukosa darah tikus

\begin{tabular}{ccc}
\hline Kelompok & Glukosa darah ke-1 $(\mathbf{m g} / \mathbf{d l})$ & Glukosa darah ke-2 $(\mathbf{m g} / \mathbf{d l})$ \\
\hline $\mathrm{K}-$ & $96.50 \pm 13.22$ & $114.17 \pm 24.45$ \\
$\mathrm{~K}+$ & $576.00 \pm 53.66$ & $588.20 \pm 26.38$ \\
$\mathrm{P} 1$ & $588.00 \pm 22.63$ & $549.75 \pm 75.67$ \\
$\mathrm{P} 2$ & $528.33 \pm 84.20$ & $491.00 \pm 243.73$ \\
P3 & $557.50 \pm 48.60$ & $600 \pm 00.00$
\end{tabular}

Tabel 2. Data rata-rata pengukuran berat badan tikus

\begin{tabular}{cccccc} 
Periode & K- & K+ & P1 & P2 & P3 \\
\hline Minggu 1 (Aklimatisasi) & $152.2 \pm 9.22$ & $144.4 \pm 4.79$ & $148.5 \pm 7.49$ & $146.6 \pm 5.34$ & $150.2 \pm 4.99$ \\
Minggu 2 (Injeksi STZ) & $162.6 \pm 18.69$ & $145.9 \pm 5.48$ & $158.0 \pm 11.96$ & $153.4 \pm 9.46$ & $152.9 \pm 14.38$ \\
Minggu 3 (Dewandaru) & $179.3 \pm 22.26$ & $160.0 \pm 12.43$ & $162.8 \pm 21.68$ & $166.4 \pm 12.70$ & $157.7 \pm 17.42$ \\
Minggu 4 & $198.2 \pm 23.95$ & $161.4 \pm 12.01$ & $175.3 \pm 22.56$ & $173.6 \pm 15.27$ & $161.4 \pm 20.66$ \\
Minggu 5 & $213.8 \pm 26.99$ & $169.0 \pm 17.62$ & $179.5 \pm 31.09$ & $175.4 \pm 18.99$ & $162.6 \pm 23.51$ \\
Rata-rata & $181.2 \pm 25.22$ & $155.9 \pm 10.83$ & $164.8 \pm 12.65$ & $163.1 \pm 12.63$ & $156.9 \pm 53.52$ \\
\hline
\end{tabular}

Tabel 3. Hasil rata-rata jumlah pembuluh darah pada seluruh lapang pandang bola mata tikus

\begin{tabular}{|c|c|c|c|c|c|c|c|c|c|}
\hline \multirow{2}{*}{ Kelompok } & \multicolumn{6}{|c|}{ Jumlah pembuluh darah } & \multirow{2}{*}{ Jumlah } & \multirow{2}{*}{ Rata-Rata } & \multirow{2}{*}{ P-value } \\
\hline & 1 & 2 & 3 & 4 & 5 & 6 & & & \\
\hline K- & 13 & 17 & 21 & 17 & 14 & 8 & 90.000 & $15.000 \pm 4.427$ & 0.000 \\
\hline $\mathrm{K}+$ & 21 & 34 & 40 & 26 & $\mathrm{X}$ & 33 & 154.000 & $30.800 \pm 7.396$ & 0.000 \\
\hline $\mathrm{P} 1$ & 12 & 19 & 19 & 6 & $\mathrm{X}$ & $X$ & 56.000 & $14.000 \pm 6.272$ & 0.000 \\
\hline $\mathrm{P} 2$ & 11 & $X$ & 13 & 10 & 7 & 14 & 55.000 & $11.000 \pm 2.739$ & 0.000 \\
\hline P3 & $X$ & 11 & 17 & 15 & 9 & 12 & 64.000 & $12.800 \pm 3.194$ & 0.000 \\
\hline
\end{tabular}

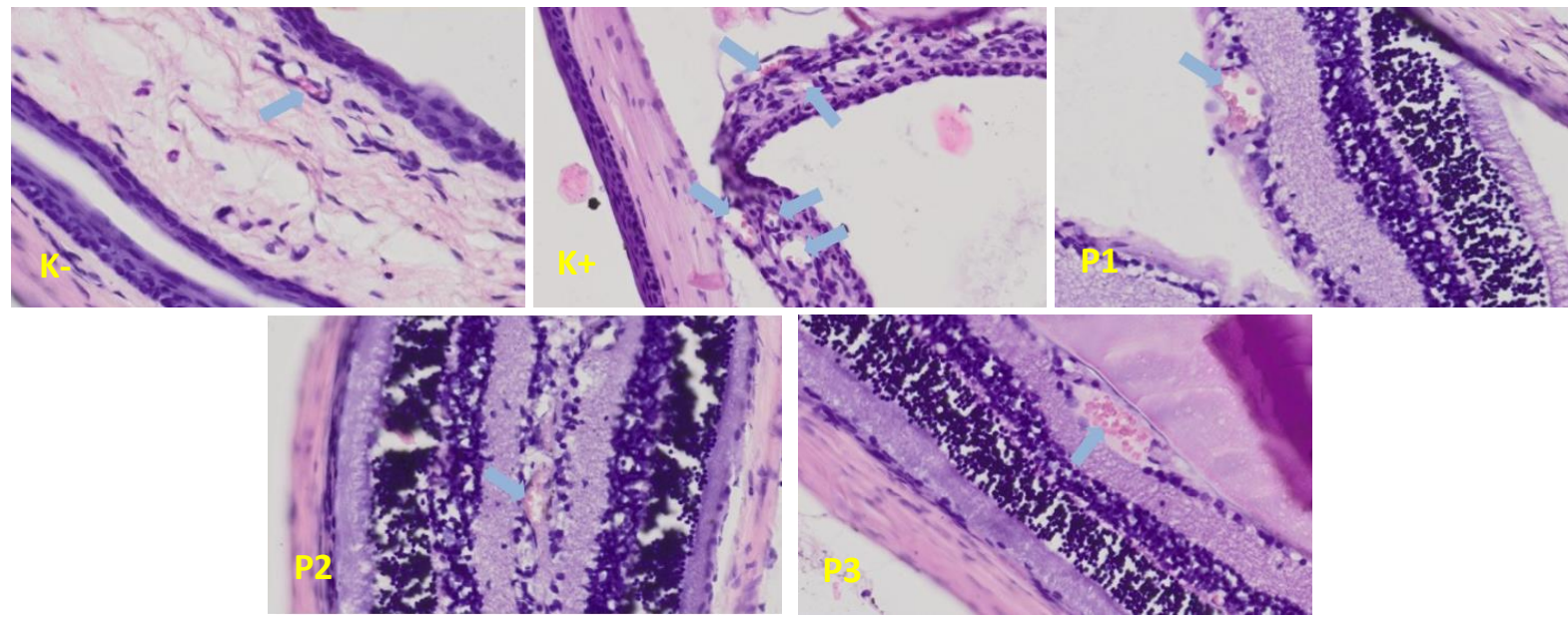

Gambar 1. Perhitungan pembuluh darah retina tikus $(\rightarrow)$ dengan pewarnaan Hematoksilin-eosin

darah tikus normal yaitu 50-135 mg/dl. Kadar glukosa kelompok $(\mathrm{K}+)$ yang diinjeksi dengan STZ menunjukkan kadar glukosa meningkat dibandingkan kelompok (K-) yaitu 576.00土53.66 $\mathrm{mg} / \mathrm{dl}$ pada glukosa darah 1 dan $588.20 \pm 26.38$ $\mathrm{mg} / \mathrm{dl}$ pada glukosa darah ke-2, yang termasuk dalam rentang kadar glukosa darah tikus DM yaitu >200 mg/dl (Tabel 1).
Pada kelompok perlakuan yaitu P1, P2, dan P3 diinjeksi STZ dan 7 hari kemudian diberi perlakuan pemberian ekstrak dewandaru dengan dosis P1: $50 \mathrm{mg} / \mathrm{kgBB}$; P2: $100 \mathrm{mg} / \mathrm{kgBB}$; P3: $200 \mathrm{mg} / \mathrm{kgBB}$ selama 1 bulan. Setelah perlakuan pada minggu ke-2, dilakukan pengukuran kadar glukosa darah dan hasilnya untuk kelompok P3 diperoleh kadar glukosa darah $557.50 \pm 48.60$ 
$\mathrm{mg} / \mathrm{dl}$ pada glukosa darah ke-1 dan $600 \pm 00.00$ $\mathrm{mg} / \mathrm{dl}$ pada glukosa darah ke-2 yang menunjukkan peningkatan kadar glukosa yang tinggi. Sementara pada P1 $588.00 \pm 22.63 \mathrm{mg} / \mathrm{dl}$ pada glukosa darah ke-1 dan 549.75 \pm 75.67 $\mathrm{mg} / \mathrm{dl}$ pada glukosa darah ke-2 dan P2 $528.33 \pm 84.20 \mathrm{mg} / \mathrm{dl}$ pada glukosa darah ke-1 dan $491.00 \pm 243.73 \mathrm{mg} / \mathrm{dl}$ pada glukosa darah ke-2 (Tabel 1).

Penelitian Zangiabadi et al., (2011), induksi DM menggunakan metode injeksi STZ dosis tunggal $40 \mathrm{mg} / \mathrm{KgBB}$ intraperitoneal. Tiga hari setelah diinduksi STZ terjadi peningkatan kadar glukosa darah yang menandakan tikus dalam keadaan diabetes dengan ketentuan glukosa darah acak lebih dari $200 \mathrm{mg} / \mathrm{dl}$. Begitu pula dalam penelitian ini, nilai mean kadar glukosa darah pada pengukuran glukosa darah 1 yang dilakukan pada 3 hari setelah injeksi STZ pada kelompok (K+), P1, P2, dan P3 didapatkan kadar glukosa darah yang sangat tinggi dibandingkan dengan kelompok (K-) 96.50 $\pm 13.217 \mathrm{mg} / \mathrm{dl}$ yaitu $(\mathrm{K}+) \quad 576.00 \pm 53.66 \mathrm{mg} / \mathrm{dl}, \quad$ P1 $588.00 \pm 22.63$ $\mathrm{mg} / \mathrm{dl}, \quad$ P2 $528.33 \pm 84.20 \mathrm{mg} / \mathrm{dl}, \quad$ dan $\quad \mathrm{P} 3$ $557.50 \pm 48.60 \mathrm{mg} / \mathrm{dl}$ yang menunjukkan kadar glukosa darah tikus yang mengalami DM yaitu $\geq$ $200 \mathrm{mg} / \mathrm{dl}$. Kadar glukosa darah paling tinggi pada kelompok P1 yaitu, $588.00 \pm 22.63 \mathrm{mg} / \mathrm{dl}$ dan paling rendah pada kelompok P2 yaitu $528.33 \pm 84.20 \mathrm{mg} / \mathrm{dl}$.

Pada pengukuran glukosa darah ke-2 didapatkan bahwa tetap terjadi peningkatan glukosa darah pada kelompok $(\mathrm{K}+)$ (tidak diberikan ekstrak Daun Dewandaru (Eugenia uniflora L.) $588.20 \pm 26.38 \mathrm{mg} / \mathrm{dl}$, dan pada kelompok perlakuan yang diberikan Ekstrak Daun Dewandaru (Eugenia uniflora L.) yaitu pada kelompok P3 $600 \pm 0.00 \mathrm{mg} / \mathrm{dl}$. Sedangkan pada kelompok perlakuan yang diberikan ekstrak Daun Dewandaru (Eugenia uniflora L.) pada kelompok P1 dan P2 terjadi penurunan glukosa darah yaitu $549.75 \pm 75.67 \mathrm{mg} / \mathrm{dl}$ dan $491.00 \pm 243.73 \mathrm{mg} / \mathrm{dl}$. Dan pada hasil mean kadar glukosa darah pada pengukuran glukosa darah ke-2 yang dilakukan 2 minggu setelah injekai STZ dan 1 minggu setelah dilakukan pemberian ekstrak Daun Dewandaru (Eugenia uniflora L.) pada kelompok perlakuan, yang paling tinggi pada kelompok P3 $(600 \pm 0.00$ $\mathrm{mg} / \mathrm{dl}$ ) dan paling rendah pada kelompok P2 (491.00 $\pm 243.73 \mathrm{mg} / \mathrm{dl})$.

Hasil didapatkan bahwa semakin besar pemberian dosis ekstrak Daun Dewandaru (Eugenia uniflora L.), maka kadar glukosa darah yang didapatkan akan semakin menurun. Dari hasil pengukuran glukosa darah ini, terjadi penurunan glukosa darah pada tikus antar kelompok perlakuan setelah diberikan ekstrak Daun Dewandaru (Eugenia uniflora L.) yaitu kelompok P1 dan P2 pada pengukuran glukosa darah ke-2, namun pada kelompok P3 terjadi peningkatan glukosa darah. Sehingga dapat disimpulkan bahwa ekstrak Daun Dewandaru (Eugenia uniflora L.) memiliki potensi menurunkan glukosa darah.

Nilai mean kadar glukosa darah ke-1 didapatkan kelompok $(\mathrm{K}+)$ lebih rendah dibandingkan dengan kelompok $\mathrm{P} 1$, hal ini dikarenakan glukosa darah awal tikus kelompok perlakuan 1 lebih tinggi daripada kelompok kontrol positif pada saat sebelum diinduksi STZ sehingga saat setelah diinduksi STZ nilai glukosa darah pada kelompok P1 lebih tinggi dibandingkan kelompok $(\mathrm{K}+)$. Nilai mean kadar glukosa darah ke-2 didapatkan kelompok $(\mathrm{K}+)$ lebih rendah dibandingkan dengan kelompok P3, hal ini dikarenakan kadar glukosa awal $(\mathrm{K}+)$ yang lebih rendah dan kedua dikarenakan terdapat satu tikus dalam kelompok $(\mathrm{K}+)$ yang glukosa darahnya tidak terlalu tinggi dibandingkan tikus lainnya dalam kelompok tersebut yaitu $541 \mathrm{mg} / \mathrm{dl}$ sehingga hasil meannya menjadi lebih rendah yang mungkin dikarenakan memiliki immunitas yang baik. Kelompok P1 tikus yang tersisa hanya 4 ekor pada pengukuran glukosa darah ke-2 yaitu 440 $\mathrm{mg} / \mathrm{dl}, 559 \mathrm{mg} / \mathrm{dl}$, dan dua lainnya $>600 \mathrm{mg} / \mathrm{dl}$. Dengan adanya tikus yang mati dan banyaknya tikus yang memiliki kadar glukosa darah $>600$ mg/dl dibandingkan dengan kelompok lainnya mungkin dikarenakan efek induksi STZ yang terus berkelanjutan dan rendahnya potensi pemberian ekstrak Daun Dewandaru (Eugenia uniflora L.) dosis tinggi yaitu $200 \mathrm{mg} / \mathrm{KgBB}$ sehingga tidak memberikan efek yang berarti 
dalam menurunkan kadar glukosa darah pada tikus.

\section{Pengukuran Berat Badan Tikus}

Data rata-rata berat badan tikus selama 5 minggu perlakuan terdapat pada tabel 2 . Berdasarkan hasil penimbangan didapatkan tikus dengan (K-) menunjukkan kenaikan berat badan yang signifikan pada minggu ke -2, minggu ke-3, minggu ke-4 dan minggu ke-5. Tikus dengan $(\mathrm{K}+)$ menunjukkan kenaikan berat badan pada setiap minggunya (minggu ke-2, minggu ke-3, minggu ke-4, dan minggu ke-5) (Tabel 2).

Tikus P1 menunjukkan peningkatan berat badan yang signifikan pada setiap minggunya (minggu ke-2 sampai dengan minggu ke-5). Sedangkan tikus P2 menunjukkan peningkatan berat badan pada minggu ke-2, minggu ke-3, minggu ke-4, dan minggu ke-5, namun tidak setinggi tikus kelompok P1. Sementara tikus P3 juga menunjukkan kenaikan berat badan pada setiap minggunya (minggu ke-2 sampai dengan minggu ke-5), namun dengan rentang kenaikan yang tidak sebanyak pada tikus kelompok P1 dan P2 pada setiap minggunya (Tabel 2).

Hiperglikemia dan penurunan berat badan merupakan gejala spesifik dari DM tipe 1 . Kondisi DM tipe 1 juga ditemukan gejala klinis yang khas pada DM seperti polyuria, polydipsia, dan polifagia. Hiperglikemia disebabkan oleh menurunnya sekresi insulin sehingga meningkatnya kadar glukosa yang beredar dalam darah (Nugroho, 2006).

Hasil mean selama 5 minggu didapatkan berat badan paling berat pada kelompok (K-) yaitu $181.21 \pm 25.221 \mathrm{gr}$ dan yang paling rendah pada kelompok $(\mathrm{K}+)$ yaitu $155.97 \pm 10.826$ gr. Berat badan paling rendah didapatkan pada kelompok dengan pemberian dosis ekstrak Daun Eugenia uniflora L. paling tinggi yaitu kelompok P3 dan berat badan paling tinggi didapatkan pada kelompok dengan pemberian dosis ekstrak Daun Eugenia uniflora L. paling rendah yaitu kelompok P1.

Dari hasil pengukuran berat badan ini, terjadi peningkatan berat badan pada tikus kelompok perlakuan P1, P2 dan P3 setelah diberikan ekstrak Daun Eugenia uniflora L..
Dapat disimpulkan bahwa ekstrak Daun Eugenia uniflora $L$. memiliki potensi untuk menaikkan berat badan.

\section{Pengecatan Hemathoxylin Eosin}

Perhitungan jumlah pembuluh darah retina tikus dilakukan menggunakan software Olyvia, dengan pembesaran 400x dan 5 lapang pandang seperti pada gambar 1. Setelah dilakukan pembagian lapang pandang dilanjutkan dengan perhitungan jumlah pembuluh darah disetiap lapang pandang dengan menandai pembuluh darah yang telah dihitung untuk menghindari penghitungan ulang (Tabel 3).

Pada Tabel 3. menunjukkan jumlah pembuluh darah yang terbentuk atau proses angiogenesis yang terjadi pada tikus selama perlakuan. Setelah dilakukan pengamatan dengan pewarnaan Hematoksilin-eosin (HE) pada retina mata tikus, didapatkan hasil terjadinya penurunan jumlah pembuluh darah pada tikus yang diinduksi STZ setelah mendapatkan terapi ekstrak daun Eugenia uniflora $L$. Berdasarkan hasil penelitian, terlihat bahwa mean jumlah pembuluh darah pada kelompok tikus (K-) yaitu 15.000 \pm 4.427 , sedangkan pada kelompok $(\mathrm{K}+)$ 30.800 \pm 7.396 yang menunjukkan bahwa terjadi peningkatan jumlah pembuluh darah pada tikus yang diinduksi STZ dan tanpa pemberian ekstrak daun Eugenia uniflora L. Sedangkan pada tikus kelompok P1 terlihat mean jumlah pembuluh darah 14.000 \pm 6.272 dan P2 mean jumlah pembuluh darah 11.000 \pm 2.739 dan kelompok P3 $12.800 \pm 3.194$ yang menunjukkan bahwa terjadinya penurunan jumlah pembuluh darah pada tikus yang diinduksi STZ dan diberikan ekstrak daun Eugenia uniflora $L$ dibandingkan dengan kelompok $\mathrm{K}(+)$ yang tidak diberikan ekstrak daun Eugenia uniflora $L$.

Hasil uji One-Way ANOVA pada penelitian ini menunjukkan terdapat perbedaan signifikan antara kelompok penelitian. Uji Post Hoc menunjukkan terdapat perbedaan signifikan antara kelompok kontrol negatif dan kontrol positif, dengan nilai mean kelompok (K-) lebih kecil dibandingkan dengan kelompok $(\mathrm{K}+)$, yang mana dapat diartikan pada kondisi setelah 
diinjeksi STZ yaitu kondisi diabetes terdapat peningkatan jumlah pembuluh darah pada retina. Uji statistik ini juga didapatkan hasil bahwa kelompok yang dilakukan pemberian ekstrak Daun Eugenia uniflora L. yaitu P1, P2, dan P3 terjadi penurunan jumlah pembuluh darah retina yang mana dapat diartikan tidak berbeda signifikan dengan kelompok (K-) dan berbeda signifikan dengan kelompok $(\mathrm{K}+)$. Berdasarkan pemaparan tersebut, dapat diketahui bahwa pemberian ekstrak Daun Eugenia uniflora $L$. efektif dalam menurunkan jumlah pembuluh darah retina pada tikus kondisi diabetes yang diinduksi STZ.

Hasil penelitian ini sejalan dengan penelitian Arifin, 2018 mendapatkan bahwa dengan adanya kandungan flavonoid salah satunya adalah Quercetin yang dapat ditemukan di banyak tanaman dengan kemampuan sebagai antioksidan dan antiinflamasi yang sangat baik dengan menangkal radikal bebas dan ion-ion transisi sehingga dapat membantu mencegah penyakit tertentu seperti kanker, aterosklerosis, dan peradangan kronis. Akhalghi and Brian, 2009 mengatakan bahwa mekanisme flavonoid dapat melindungi dari reaksi lanjutan ROS dan sebagai inflamasi dengan menghambat terbentuknya sitokin proinflamasi seperti TNF- $\alpha$, IL-6, IL-1 $\beta$ dan interferon- $\gamma$ dimana dapat menghambat proses angiogenesis (Hamid et al., 2018). Kandungan flavonoid terutama quercetin dalam Daun Eugenia uniflora L. membantu menurunkan pembentukan pembentukan pembuluh darah baru yang terbentuk.

\section{KESIMPULAN}

Dapat disimpulkan bahwa pemberian ekstrak Daun Eugenia uniflora L. pada tikus Wistar dengan kondisi diabetes yang diinduksi STZ berpotensi menurunkan respon angiogenesis pada retina tikus.

\section{UCAPAN TERIMA KASIH}

Penulis mengucapkan terimakasih kepada Ibu dan Ayah, Nanik Andayani, S. TP dan Djoko Soengkowo, SE., MAP, serta kakak saya tercinta
Chamelia Rohadatul Aissy, dr., S.Ked., M.Biomed yang telah memberikan do'a, semangat, dan dukungan yang tiada henti. Pencapaian masa pendidikan ini saya persembahkan untuk mereka.

\section{DAFTAR PUSTAKA}

Akhalghi, M., Brian, B. 2009. Mechanism of Flavonoid Protection Against Myocardial ischemia-reperfusion injury. J. Mol. Cell. Cardiol., 46, 309-17.

Arifin. 2018. Struktur, Bioaktivasi, dan Antioksidan Flavonoid. J. Zarah, 6(1), 2129.

Badan Penelitian dan Pengembangan Kesehatan Kementrian Kesehatan RI (Balitbang Depkes RI). 2013. Riset Kesehatan Dasar (Riskesdas): Laporan Nasional. Jakarta: Badan Litbangkes RI.

Cunha-Vaz, J. 2011. Diabetic Retinopathy. Singapore. World Scientific Publishing Co. Pte. Ltd.

Diabetic Retinopathy Guidelines. 2012. The Royal College of Ophthalmologists. London.

Gupta, N., Mansoor, S., Sharma, A., Sapkal, A., Sheth, J., Falatoonzadeh, P., Kuppermann, B., Kenny, M. 2013. Diabetic Retinopathy and VEGF. The Open Ophthalmol. J., 7, 410.

Hamid, I.S., Aksono, E.B., Sukmanadi, M., Purnama, M.T.E. 2018. Antiangiogenesis activity test of tin leaf (Ficus carica L.) on the number of blood vessels and VEGF expression of chorioallantoic membrane of embryonated chicken eggs. Eur. J. Oncol. Pharm., 1(4), e00007.

Hamid, I.S., Ekowati, J., Purnama, M.T.E. 2019. Kaempferia galanga L. Inhibiting Effect on Vascular Endothelial Growth Factor (VEGF) and Cyclooxygenase-2 (Cox-2) Expression on Endothelium of Chorioallantoic Membrane. Indian Vet. J., 96(09), 80-82.

Kusumowati, Ika Trisharyanti Dian. 2010. Uji Kombinasi Ekstrak Etil Asetat Daun Dewandaru (Eugenia uniflora L.) dan 
Doxorubicin Terhadap Proliferasi Sel Kanker Payudara T47D. Surakarta: LPPM Universitas Muhammadiyah.

Nugroho, A.N. 2006. Hewan Percobaan Diabetes

Mellitus: Patologi dan Mekanisme Aksi Diabetogenik. Laboratorium Farmakologi dan Toksikologi. Fakultas Farmasi Universitas Gadjah Mada, Yogyakarta.

Sitompul, R. 2011. Retinopati Diabetik. J. Indon. Med. Assoc., IDI., 61, 338.
Soebagijo, S. 2015. KONSENSUS Pengelolaan dan Pencegahan Diabetes Mellitus tipe 2 di Indonesia 2015. Jakarta: PB PERKENI.

Zangiabadi, N., Sheibani, V., Asadi-Shekaari, M., Shabani, M., Jafari, M., Asadi, A.R., Jarahi, M. 2011. Effects of melatonin in Prevention of Neuropathy in STZ-Induced Diabetic Rats. Am. J. Pharmacol. Toxicol., 6(2), 59-67. 